\title{
GOOD GOVERNANCE SEBAGAI MODEL RETORIS
}

\author{
Teguh Priyo Sadono \\ Magister Ilmu Komunikasi, Universitas Bunda Mulia \\ Alamat surel: tsadono@bundamulia.ac.id
}

\begin{abstract}
Throughout the history of the state of life, a nation are always colored tidal beliefs of the management of the State. Various approaches are used through policy model be pursued in the conception of the ideal model of building a nation in achieving its goals. Start with the assumption state approach as an effective phrase, shifted to Market and civil society did not obtain a formula that considered the most effective. Then came the views of good governance is regarded as a dynamic view and dialectics approach in the management of government supervision. However, in the implementation of global factors strongly influence national policy models, So Good Governance merely a rhetorical concept that can not be applied in empirical level.
\end{abstract}

Keywords: approaches, state, market, civil society, Governance

\begin{abstract}
Abstrak
Sepanjang sejarah kehidupan bernegara suatu bangsa selalu diwarnai pasang surut keyakinan tentang pengelolaan Negara. Berbagai pendekatan yang digunakan melalu model kebijakan terus diusahakan dalam konsepsi bagi model ideal membangun bangsa dalam mencapai tujuannya. Mulai pendekatan state dengan asumsi sebagai frasa efektif, bergeser ke Market dan civil society tidak memperoleh formula yang dianggap paling efektif. Kemudian muncul pandangan good governance dianggap sebagai pandangan pendekatan yang dinamis dan dialectics dalam manejemen pengelolaan pemerintah. Namun demikian dalam implementasinya factor global sangat mempengaruhi model kebijakan nasional, Sehingga Good Governance hanya merupakan sebuah konsep retoris yang tidak dapat diterapkan dalam tataran empiris.
\end{abstract}

Kata kunci: Pendekatan, Negara, Pasar, Masyarakat sipil, Governance

\section{PENDAHULUAN}

Hubungan negara, pasar dan masyarakat sipil sebagai domain pemerintahan secara akademik terus terjadi perdebatan menyangkut beberapa pendekatan yang berbeda. Berbagai pendekatan yang dianggap paling efektif dalam menjalankan sistem pemerintahan telah mengalami berbagai perubahan bentuk jalinan hubungan ketiga domain tesebut. Adapun perubahan pola hubungan tersebut adalah hubungan yang lebih mengedepankan peran negara atau state center, hubungan yang lebih mengedepankan pasar atau market center, hubungan yang lebih menekankan masyarakat sipil atau civil society center dan pendekatan yang lebih menekankan keseimbangan ketiga domain pemerintahan dalam triangle relation yang di sebut sebagai good governance. Pandangan-pandangan tersebut adalah sebagai pandangan dinamis dan dialektis dalam manejemen pengelolaan pemerintahan.

\section{Pendekatan yang berpusat pada Negara (State center)}

Negara sebuah frasa yang selalu menjadi pusat kajian ketika mengupas tentang pengaturan kehidupan bersama dalam batasan tertentu. Namun demikian mendefinisikan negara tidaklah mudah yang sebagian dikarenakan hakekat hubunganya yang bersifat problematis dengan masyarakat sipil ataupun pasar, sebagian lagi karena arti pentingnya yang tidak dapat diragukan dalam teori politik dan sosial. Dulevy dan O'leary memberi definisi yang relatif lebih komprehensif dengan strategi definisi organisasional dan definisi fungsional. Secara organisasional negara adalah satu set lembaga-lembaga pemerintahan yang selalu berkembang

Jurnal Bricolage Vol. 2 No. 2 
sepanjang sejarah. Pemerintahan disini adalah suatu proses pembuatan aturan, mengontrol, memberi petunjuk atau mengatur. Beberapa bentuk pemerintahan adalah secara intrisik ada pada human society karena masyarakat secara keseluruhan tidak terkontrol, tak terarah, tak teratur sebagai kondisi yang kontradiktif. Sementara secara fungsional negara sebagai suatu set institusi akan mengemban berbagai bentuk tujuan, maksud dan objek yang terpisah-pisah. Negara adalah sebuah konsekuensi untuk memelihara sosial order, sebagai bentuk-bentuk perilaku yang mempunyai pengaruh menstabilisasikan masyarakat.

Ketika kesadaran negara muncul, upaya mengukuhkan kekuasaan untuk mengesahkan dirinya dinilai sebagai hal yang wajar, sejauh kekuasaan yang dianggap sah oleh masyarakatnya dan memang diperlukan untuk memperlancar pelaksanaan pemerintahan. Sedang negara (Mann, 1988) yang dikutip Roode negara adalah sebagai institusi unik yang dapat secara teritorial memusatkan kekuasaanya, oleh karena itu menjadikannya relatif kuat dan menjadi wadah kekuasaan dibandingkan dengan sifat masyarakat sipil yang terpecahpecah, negara memusatkan kekuatan militer, ekonomi, dan komunikatif. Munculnya negara sebagai bentuk organisasi politik berbarengan dengan munculnya sistem kekuasaan. Kekuasaan mengambil bentuk yang beraneka ragam dengan orientasi kekuatan berada pada negara. Berbagai bentuk perbedaan yang paling penting pada rezim otoriter adalah pada dimensi despotism yaitu seberapa jauh kekuatan politik itu dimainkan tanpa batas. Juga penetrasi yaitu seberapa jauh kekuatan politik itu mengatur kehidupan sehari-hari warganya. Perbedaan tekanan pada dimensi despotism dan penetrasi tersebut berada dalam kontinum diktaktor partai tunggal dan negara otoriter.

Esensi karakteristik masyarakat otoritarian adalah negara sebagai perangkat tertinggi dari individu di dalam skala nilainilai sosial, hanya melalui subordinasi negara, individu dapat mencapai tujuannya dan membangun atribut kewarganegaraan. Di samping itu negara tidak hanya sebagai perangkat individual, tetapi juga mengambil alih banyak fungsi penting termasuk pasar, dimana individu dan pasar mempunyai peringkat ketergantungan terhadap negara sangat tinggi. Hegel dengan konsep dialektikanya, mengatakan bahwa negara adalah ungkapan roh objektif, dimana roh objektif tersebut merupakan cerminan dari kehendak, pikiran dan hasrat masing-masing individu. Dengan demikian negara merupakan institusi yang paling paham akan kehendak para individu; rakyat tak mengetahui kehendaknya, yang mengetahui adalah negara, karena ia secara "objektif" mengungkapkan apa yang bagi rakyat hanya ada secara "subjektif".

Bagi Hegel, hubungan antara individu dipahami sebagai beroperasi dalam tiga ruang lingkup utama: Keluarga, masyarakat sipil dan negara. Masing-masing dari ketiga ruang lingkup ini dipandang sebagai sebuah tahap dalam perkembangan evolusioner menuju kebebasan yang merupakan kesempatan untuk berpartisipasi di dalam "kehidupan etis". Keluarga dan masyarakat sipil sebagai wilayah-wilayah pengembangan kepentingan diri dan masyarakat sipil menghasilkan pandangan dan menginginkan penggerusan fisik dan etis dari keduanya. Sebaliknya, negara adalah aktualitas dari prinsip etis dan merepresentasikan bentuk tertinggi dari komunitas manusia. Negara diyakini akan mampu mengelola dan mengembangkan kesejahteraan dan tujuan masyarakat yang direpresentasikan.

Keyakinan negara sebagai sumber kebenaran tertinggi dari prinsip etis menempatkan paradok hubungan negara dan masyarakat sipil pun lahir. Pemisahan antara negara dan masyarakat sipil terjadi dalam upaya-upaya birokrasi dalam kepentingan kolektif. Kenyataan ini dapat pula dimungkinkan terjadi sebagai reaksi atas penolakan nilai kebenaran dan munculnya keyakinan baru di dalam suatu negara yang mulai berpaling dari sebuah kebenaran sebelumnya. Pemikiran baru Otoritarian yang tumbuh dari kesadaran akan kebebasan 
individu dari kungkungan kediktaroran, telah memunculan state capitalism, sebagai sebuah tata nilai baru. Perilaku otoritatif dalam tata nilai baru democratic state atau state capitalism, tidak lagi hanya menyangkut preferensi hubungan negara dan masyarakat sipil namun juga menyangkut otonomi pasar sebagai realitas kelompok kekuatan yang ada dalam relasi tersebut.

Sebagai sebuah pendekatan state center yang muncul dari revolusi intelektual, yang didasarkan pada konsep Karl Marx yang kemudian berkembang di Uni soviet dan China ini, menempatkan negara sebagai representasi dari mayoritas masyarakat atau publik. Representasi publik berada dalam organisasi politik yang menguasai negara untuk menjaga idiologi sosialis yang berorientasi pada hilangnya lembaga negara. Pemikiran Marxis yang membongkar keterkungkungan kelas, sebagai sebuah kesadaran baru untuk menentang atas dominasi kaum bourjuis yang menguasai alat produksi, karena kapitalisme adalah suatu sistem yang eksploitatif, yang menyebabkan ketidaksetaraan kekuasaan yang meluas. Sementara negara digunakan sebagai alat kaum mayoritas dengan kepentingan dominan dalam masyarakat sipil.

Negara dalam hubungannya dengan masyarakat sipil, negara dipisah secara tegas dengan masyarakat sipil. Di sini negara dianggap sebagai agen perubahan, negara sebagai sumber inovasi bagi kemajuan masyarakat sipil, oleh sebab itu negara harus memiliki otoritas yang melampaui otoritas individu atau masyarakat. Pada pendekatan ini negara tampil sebagai aktor utama berperan melancarkan regulasi politik, redistribusi ekonomi dan kontrol yang kuat terhadap ruang-ruang politik dalam masyarakat. Implikasinya adalah meningkatnya pengeluaran pemerintah untuk pelayanan publik, meluasnya program-program politik dan investasi ke dunia pasar. Negara dianggap sebagai motor yang tangguh, absah dan tidak tertandingi untuk membawa perubahan sosial dan ekonomi.
Dalam kaitan dengan otonomi pasar, Marx mengatakan bahwa hanya dengan perkembangan kapitalisme yang kendalikan negara melalui pengaturan pasar maka masyarakat sipil bisa berkembang sepenuhnya. Dan kaum Marxis menolak individualisme abstrak ala liberalisme dan sebaliknya memahami perilaku manusia dalam konteks sosialnya, dimana kegiatan masyarakat dibentuk-bahkan ditentukan oleh kedudukan mereka dalam sistem ekonomi, dan negara akan menyokong dan berusaha mendamaikan untuk kepentingan jangka panjang kapitalisme. Sehingga kedudukan pasar akan berada dalam pengendalian negara demi kepentingan reperesentasi etis tertinggi dari masyarakat sipil.

Samuel P. Huntington dalam Martinussen mengemukakan bahwa aparatus negara akan mengendalikan pengembangan dan proses politik dengan cepat melalui kelembagaan lama untuk memulai proses pembangunan sosial politik. Hal ini merupakan prakondisi yang penting untuk stabilitas politik dan konsekuensi dari pengembangan yang berkelanjutan. Dan lebih spesifik hal tersebut sebagai komponen-komponen dari civil administration dengan pertanggungjawaban pada hukum dan sosial order, seperti penguasan militer sebagai penekan pada fase awal. Sehingga keberadaan negara menjadi sangat penting bagi kemajuan bangsa. Namun dalam pelaksanaanya penempatan negara dalam mengendalikan pemerintahan memiliki tipologi bermacam-macam dapat berupa sentralisi atau desentralisasi, kapitalis atau sosialis.

Apapun bentuk tipologi negara, ketika negara diyakini sebagai representatif etis tertinggi dan rasional maka pengendalian kapital ada pada negara. Dengan memegang kewenangan yang tinggi pada negara memberi peluang terjadinya tindakan represif, dimana tujuan utamanya hanya politik. Demikian pula dalam relasinya dengan kapitalisme, peran inti yang dimainkan negara suatu saat akan dikolaborasikan dengan kaum kapitalis sehingga membangun ruang pasar tersendiri. Tekanan represif negara mengakibatkan

Jurnal Bricolage Vol. 2 No. 2 
lemahnya kekuatan masyarakat sipil, sehigga artikulasi individual dan hakekat masyarakat secara individu dinisbikan.

Namun demikian perubahanperubahan orientasi tentang pemerintahan dalam pendekatan state center tersebut, karena batasan struktural maka negara ditempatkan pada fungsi primernya yakni mempertahankan kondisi bagi akumulasi kekuasaan dan kapital. Realitas ini termasuk mengendalikan dan memelihara stabilitas sosial dan politik, memberikan dukungan infrastruktur dan melangsungkan pasar tenaga kerja yang tepat. Implikasi dari hal ini muncul super determinism struktural dimana individu sebagai agen perubahan tidak relevan dan pasar sebagai penggerak perubahan ekonomi tidak berarti. Hal ini yang kemudian memunculkan pemikiran baru tentang peran relatif negara atas individu dan pasar.

\section{Pendekatan yang berpusat pada Pasar (Market center)}

Tumbuhnya kesadaran intelektual yang memunculkan kesadaran baru tentang konsepsi hakekat manusia dalam hubungannya dengan negara, telah mengubah pendulum dari state center ke arah liberal capitalism. Dalam rangkaian penemuan-penemuan ilmiah dan tata geografis menunjukkan adanya kesadaran baru yang memperbesar harkat manusia. Meningkatnya kekuatan kelas pedagang mendorong mereka mempertanyakan hakhak istimewa kaum bangsawan, dan mulai menentang supremasi pemerintahan otoriter. Konsepsi kebebasan dalam iklim libertarian terus berkembang dan menumbangkan otoritarian.

Beberapa pandangan tentang libertarian dapat di lihat dari pandangan kaum libertarian abad 18. Seperti John Struat Mill, Oliver Wendell Holmes. Mill melihat bahwa kebebasan adalah hak bagi setiap orang dewasa untuk berfikir dan bertindak sesuai keinginannya, sejauh itu tidak merugikan orang lain. Mill juga memandang perlunya kebebasan berekspresi, namun bukan sebagai hak alamiah manusia melainkan fungsi dan kegunaannya sebagai kontrol. Pemerintah yang secara historis cenderung menekan kebebasan untuk mempertahankan supremasinya. Namun juga dikemukakan bahwa kekuatan mayoritas bisa pula menindas minoritas yang mapan yang cenderung mengabaikan suara minoritas.

Terdapat empat argumen tentang perlunya kebebasan, pertama, jika kita membungkam suara tertentu, bisa jadi kita membungkam kebenaran. Kedua, pendapat yang salah pun mungkin saja mengandung aspek kebenaran tertentu yang diperlukan untuk memahami kebenaran secara utuh. Ketiga, pendapat yang sudah di terima secara umum mungkin saja benar, namun orang-orang tidak akan menerima secara rasional kalau mereka tidak ditantang untuk mempertahankannya. Keempat jika pendapat-pendapat umum tidak dikritisi dari waktu ke waktu, maka vitalitasnya akan pudar dalam arti pengaruhnya baiknya terhadap tindakan dan karakter pengaruhnya akan hilang.

Pandangan Mill tetang liberalisasi mengungkapkan sebuah kekawatiran tentang adanya anggapan bahwa kebenaran itu datangnya dari pemerintah. Dengan dikatakan bahwa kebebasan baru menang jika pemerintah bisa dibuat menghormati kebebasan. Oleh sebab itu penaklukan atas otoritas pemerintah menjadi jalan utama menuju kebebasan. Sementara itu pandangan Oliver Wendell Holmes teori libertarian mulai mengalami penyempitan cakupan, seperti halnya Milton dan kaum libertarian abad 18, Holmes mengakui pergulatan gagasan merupakan cara menuju kebenaran, namun kebenaran baginya adalah lebih bersifat pragmatis. Dan kebebasan berekspresi menurutnya membuat orangorang selalu berbeda pendapat, sekaligus memungkinkan mereka memilih yang terbaik. Seperti yang disampaikan Mill kebebasan itu penting bukan karena hal alamiah, melainkan karena berfungsi sebagai katup pengaman bagi masyarakat demokratis.

Kaum libertarian melihat kekuatan faktual yang mempunyai potensi memaksakan dominasinya dalam 
menentukan arah kebenaran adalah pemerintah. Karena setiap pengendalian pemerintah mempunyai kecenderungan menunggangi kebebasan dan hak milik rakyat. Banyak penelitian memperlihatkan bahwa dominasi dan hegemoni kekuasaan pemerintah berpotensi terjadinya pengebirian dan pengkerdilan pandangan di luar kekuasaan. Kekuasan sendiri sebagai kekuatan untuk memaksakan kehendaknya kepihak lain untuk diterima atau dilaksanakan.

Oleh karena itu kaum liberal, menganggap negara adalah sesuatu yang jahat, namun tetap diperlukan untuk melayani masyarakat sipil dan bertangung jawab kepada rakyat melalui perwakilan politik. Fungsi negara terutama untuk memelihara tertib sosial internal dan melindungi masyarakat sipil dari ancaman eksternal terhadap keamanannya, artinya negara akan menjadi penengah yang netral bagi kepentingan yang berkonflik. Negara tidak didominasi oleh sebagian anggota masyarakat, melainkan mengupayakan kebijakan untuk memaksimalkan kebebasan individu.

Hilangnya peran negara dalam sistem libertarian yang mengagungkan kemampuan individu secara intelektual dan ekonomi, menempatkan kemampuan individu secara optimal di atas keberadaan negara. Dalam teori libertarian bahwa keberadaan negara hanya untuk menjaga dan melindungi lingkungan dimana manusia dapat membangun potensi mereka dan menikmati kebahagianya secara maksimal. John Stuart Mill dalam Siebert melihat bahwa kebebasan untuk memperoleh kebenaran terjadi di market place pertukaran ide berkembang diruang tersebut. Sehingga tugas masyarakat harus menjaga sebuah free market place atas ide-ide sebagai pilihan. Adam Smith menahbiskan "Absolut Pasar" bahwa pasar dapat mengatur dirinya sendiri bila diberi kebebasan.

Liberalisme dalam sistem pasar dengan kompetisi penuh (free fight competition) pasar memiliki ruang terbuka untuk saling berebut kemenangan. Kondisi tersebut mengakibatkan suburnya bagi perkembangan kapitalisme dan azas laissez faire dimana negara tidak campur tangan untuk saling berebut, namun kompetisi ini dianggap memajukan kemakmuran umum dengan mendorong inovasi individu. Pemikiran ini menurut Chomsky bahwa penekanan adanya privatisasi atau hak-hak pribadi dan keyakinan pada tanggung jawab individual dalam mekanisme pasar bebas tersebut akan muncul usaha ekonomi korporat yang merupakan perluasan dari definisi hak-hak pribadi yang dilindungi.

Di negara-negara dunia ketiga, ketika terjadi perluasan proyek developmentalisme (modernisasi) yang ditandai dengan terjadinya westernisasi, dimana negara pengendali utama, dan kemudian terjadi krisis ekonomi dan financial telah mengeser peran negara (pemerintah). Pemerintah bukan lagi sebagai solusi terhadap problem yang dihadapi, melainkan justru sebagai akar masalah krisis. Pemikiran kaum liberal-pun mewarnai masyarakat dunia ke tiga, berbagai "penyesuaian struktural" dalam bentuk deregulasi, debirokratisasi, privatisasi dan pelayanan publik yang berorientasi pasar. Sementara di sektor politik terjadi gelombang demokratisasi yang ditandai dengan rontoknya sejumlah rezim otoritarian di kawasan Amerika Latin, Eropa Timur, Asia dan Negara-negara di Afrika.

Di samping itu pandanganpandangan tentang keberadaan pasar yang steril, pasar akan berjalan otomatis, dan akan stabil kembali ketika terjadi goncangangoncangan internal dalam pasar tidak terbukti. Demikian pula padangan tersebut tidak mampu menjelaskan persoalan dengan utuh, dimana ekonomi pasar dan negara diandaikan ada kondisi yang selalu antagonis, ternyata negara harus mengambil bagian untuk menyeimbangkan pasar ketika tejadi goncangan. Oleh sebab itu dalam berbagai pelaksanaannya pola pemusatan pasar mengalami berbagai bentuk yang berbeda.

Berbagai pola pemusatan pada pasar tersebut dalam hubunganya dengan negara terus mengalami perubahan dalam 
mainstream besar yang paling tidak dapat ditandai dari teori ekonomi klasik (liberal), Marxian, Keynsian dan Neoliberal, yang semua menempatkan pasar sebagai pusat orientasi dalam mengelola pemerintahan.

\section{Pendekatan yang berpusat pada Masyarakat Sipil (Civil Society Center)}

Beberapa teori tentang sistem sosial politik dalam relasi negara, pasar, masyarakat sipil, nampak bahwa teori yang memusatkan relasi dalam orientasi negara maupun pasar menunjukan bahwa tetap terjadi dominasi dan hegemoni oleh kekuatan dominan terhadap mayoritas masyarakat. Realitas tersebut melahirkan sintesis dari dialektika state capitalism dan Liberal capitalism yang memunculkan teoriteori masyarakat sipil. Konsep masyarakat sipil sendiri merupakan konsep lama, berdasarkan konsep pencerahaan. Istilah pentingnya diperoleh sejak tahun 1980 dengan munculnya gerakan sosial di Eropa Timur khususnya gerakan solidaritas di Polandia.

Konsep masyarakat sipil adalah berhubungan erat dengan dua konsep lainya, "demokrasi" dan "hak asasi manusia". Demokrasi adalah seperangkat prinsipprinsip pengaturan dan metode yang membela kebebasan manusia. Demokrasi adalah pelembagaan kebebasan berdasarkan pemerintah oleh mayoritas dan menjaga perorangan dan hak-hak minoritas, untuk menghormati tuntutan mayoritas dan membela hak-hak individu dan juga kelompok minoritas. Konsep yang merubah teori sebelumnya dengan melakukan diferensiasi struktural yang lebih besar dan pluralisme politik mendorong terjadinya perubahan relasi antara negara, pasar dan masyarakat sipil.

Beberapa konsep masyarakat sipil adalah produk spesifik dari negara bangsa dan kapitalisme, yang lain melihat sebagai ekspresi universal kehidupan kolektif individu, yang bekerja di semua negara dalam tahap-tahap perkembangan, yang disajikan dalam cara yang berbeda sesuai dengan sejarah dan konteks. Beberapa melihat bahwa masyarakat sipil terpisah dari assosiasi pasar dan negara, di pihak lain ada saling terkait erat dengan pasar dan negara. Masyarakat sipil, apakah berorientasi mempertahankan kelompok-kelompok yang ditetapkan dalam demokrasi modern, atau ke berbagai bentuk asosiasi seperti kelompok agama, milisi-milisi tertentu, atau didasarkan pada karakteristik asosiasi tradisional etnis atau warisan agama, akan mewarnai konsep masyarakat sipil.

Berkaitan dengan relasi kekuasaan pada masyarakat sipil, pemikir pluralis Dahl dan Truman memandang bahwa kekuasaan tersebar diseluruh masyarakat, tanpa satu pun kepentingan kelompok mendominasi, dan tiap-tiap sumber kekuasaan diimbangi oleh kekuatan penyeimbang. Penganut pluralis, proses politik dalam masyarakat liberal tidak dapat direduksi menjadi persoalan kepemilikan sarana produksi, seperti dalam Marxisme, atau menjadi distribusi ciri-ciri psikologis atau kemampuan ekonomi yang tidak setara seperti dalam teori elite kapitalistik. Kekuasaan juga tidak menumpuk, dalam pengertian bahwa sekelompok individu dapat memaksakan keinginan mereka dalam setiap situasi dan setiap waktu. Dunleavy, melihat pluralisme sebagai perlawanan atas penguasaan negara, sebagai nilai kelompok yang dikembangkan, dan otonomi secara organisasional. Pluralism juga mengagap bahwa konflik-konflik yang kuat dalam kelompok harus di harapkan ada di dalam banyak masyarakat yang komplek dan debat relatif begitu bermanfaat bagi institusi atau social checks and balances sebagai mekanisme preventif terhadap penguasaan negara. Oleh karena itu distribusi kekuasan akan tercermin dari terbentuknya kelompok penekan, partai politik yang melembagakan pembagian kekuasaan tersebut. Namun demikian poin utamanya ada pada sistem demokrasi, dengan masyarakat sipil bebas berdasarkan atas hak asasi.

Seperti dalam gagasan liberal, negara dipandang sebagai penengah diantara perselisihan kepentingan, sekaligus mencerminkan dalam bentuk konstitusional dengan konsensus umum yang dilandasi kepentingan masyarakat sipil. Sementara

Jurnal Bricolage Vol. 2 No. 2 
pasar dijadikan sarana perebutan sumber daya ekonomi yang dibutuhkan dalam menjalankan kekuasaan. Kepentingan bisnis dan keuangan menguasai struktur ekonomi dan institusional untuk mengorganisir diri mereka sendiri menjadi kelompok berpengaruh.

Beberapa normatif secara primordial, teori-teori civil society telah bergerak untuk menghidupkan konsep-konsep romantik dari komunitas lokal sebagai dasar dan kerangka kerja cukup untuk kesejahteraan manusia. Dan teori ini mempercayai bahwa keberadaan negara adalah bagian dari problem dalam pencapaian tujuan, oleh karena itu sejauh mungkin dihindarkan. Teori ini berkeyakinan penguatan komunitas lokal yang mandiri merupakan langkah yang strategis dalam peningkatkan perilaku yang baik untuk mencapai tujuan akhir mereka. Alternatif pembangunan dapat diciptakan dan berkesinambungan pada komunitas lokal yang kecil dan secara konsisten yang berseberangan dengan negara. Namun demikian bahwa pembangunan tidak dapat diakhiri di situ, sehingga tetap perlu kolaborasi dengan negara.

Deregulasi yang mewarnai tipe ini memberikan otonomi pada entitas-entitas tertentu untuk mengembangkan diri tanpa harus terikat dalam relasi vertikal dengan negara. Entitas-entitas ekonomi akan berelasi dengan masyarakat sipil dalam informal economic activities. Sementara entitas polical community berinteraksi dengan organisasi kepentingan dalam ekonomi korporasi, sedang dengan negara dalam bentuk legeslasi. Tipe ini sebagai bentuk pembangunan alternatif yang melibatkan dalam poros horisontal yang melalui poros negara dan pasar dalam interrelasi civil society dan komunitas politik. Tipe ini dikenal sebagai korporasi dalam penanganan masalah kemiskinan dan ketimpangan sosial.

Pemikiran tentang teori masyarakat sipil klasik mulai dikritik karena menjadi justifikasi idiologi atas ketidaksetaraan dalam sistem kapitalis apalagi sebagai sebuah pemikiran realistis mengenai hubungan antara negara dan masyarakat sipil. Pemikiran klasik lebih mencermati hambatan struktural terhadap partisipasi kelompok tertentu, yang kemudian diperjelas dengan munculnya neo pluralis tetang ketimpangan antar kelompok kepentingan. Richardson dan Jordan mengembangkan pemikiran tentang pluralis elit yang menyatakan bahwa masyarakat liberal itu bersifat demokratis, karena meskipun para elite mendominasi partai dan kelompok penekan, dan tak terlepas dari fakta bahwa sebagian elit lebih kuat dari yang lainnya, tidak ada kelas penguasa tunggal. Oleh sebab itu, kaum elite dipaksa untuk berkompromi dengan kelompok kekuasaan lain dan mencari dukungan dari basis sosial seluas mungkin untuk memberi bobot demokratis kepada kepentingan mereka.

Sementra Edward mengindentifikasi masyarakat sipil dari cita-cita untuk hidup berdampingan secara damai, yang melihat masyarakat sipil ke dalam tiga jenis teori masyarakat sipil. Yaitu masyarakat sipil sebagai kehidupan asosiasi, masyarakat sipil sebagai good society, dan masyarakat sipil sebagai ranah publik.

Masyarakat sipil sebagai kehidupan asosiasi, bahwa asosiasi terjadi secara sukarela, bertindak sebagai pembawa gen masyarakat baik-Microclimates. Hal ini terjadi jika mengembangkan nilai-nilai seperti toleransi, kerjasama dan ketrampilan hidup dalam iklim demokratis. Permasalahannya asosiasi adalah sumber dari berbagai macam perbedaan dan nilainilai yang bersaing. Masalah lain adalah nilai-nilai dan keyakinan akan hal yang dikehendaki dikembangkan dan dibina diberbagai tempat sebagai predisposisi seperti keluarga, sekolah, tempat kerja, lembaga politik besar ataupun kecil. Oleh sebab itu berbagai LSM dan asosiasi jarang bisa menjamin tingkat konsensus politik yang dibutuhkan dalam mengamankan dan menegakkan reformasi sosial berbasis luas, terlalu banyak perbedaan dan keragaman pendapat. Itu sebabnya John Keane masyarakat sipil "penuh bahaya, karena

Jurnal Bricolage Vol. 2 No. 2 
memberikan kebebasan untuk lalim dan demokrat secara bersamaan"

$\begin{array}{rrrr}\text { Masyarakat } & \text { sipil sebagai good } \\ \text { society, bahwa asosiasi sukarela }\end{array}$ memberikan kontribusi yang penting dalam konteks yang tepat, menjadi penjaga terhadap kecenderungan adanya hak istimewa dari satu bagian masyarakat atas masyarakat yang lain dengan alasan idiologi. Sehingga tetangga yang baik tidak dapat mengantikan pemerintahan yang baik, organisasi nirlaba tidak boleh menggantikan pasar yang telah berfungsi baik. Untuk itu guna untuk mencapai tujuan masyarakat yang baik selalu didasarkan pada kontrak sosial yang dinegosiasikan antara pemerintah, bisnis dan masyarakat.

Masyarakat sipil sebagai ranah publik, konsep "publik" sebagai sebuah pemerintahan secara keseluruhan peduli akan kepentingan umum dan memiliki kapasitas untuk membicarakan tentang hal tersebut secara demokratis, dan ini pusat pemikiran masyarakat sipil. Dalam perannya sebagai 'ranah publik' masyarakat sipil menjadi arena untuk argumen dan pertimbangan secara berserikat dan kelembagaan kolaborasi. Sejauhmana ruang tersebut berkembang menjadi penting bagi demokrasi. Namun jika hanya beberapa kebenaran yang diwakili dan sudut pandang alternatif dibungkam atau satu set suara lebih lantang dari yang lain, maka kepentingan umum akan terabaikan. Ketika semua politik terpolarisasi masalah kebijakan publik akan beku.

Faulks melihat bahwa pluralisme gagal menyadari struktur kuasa yang tidak setara telah menyelimuti negara maupun masyarakat sipil. Oleh karena itu mereka menganggap negara adalah netral dalam hubungannya dengan berbagai kepentingan yang bersaing dalam masyarakat sipil adalah naif. Untuk itu dalam mengatasi problematis relasi tersebut harus melampaui teori pluralis klasik, masuk ke pemikiran membangun relasi seimbang antara ketiganya. Yang oleh Edward dikenal dalam konsepsi masyarakat sipil sebagai good society ataupun sebagai ranah publik. Demikian pula memunculkan sebuah konsepsi dalam management pemerintahan yang memberikan tekanan tiga domain pemerintahan dalam relasi yang sejajar.

\section{Pendekatan berorientasi pada good governance}

Konsepsi yang memberikan perspektif baru tentang peran negara, pasar dan masyarakat sipil bersinergi dalam relasi yang sejajar, sebagai cara pandang baru tentang management pemerintahan. Pada cara pandang lama pemerintah yang sangat identik dengan kekuasaan, penguasaan, kewenangan, dominasi, pemaksaan mulai dirubah dengan mensinergikan ketiga domain tersebut. Pada dekade 1990-an cara pandang tentang pemerintah (government) telah mengalami perubahan dengan mempertanyakan kembali peran pemerintah dan apa yang harus dilakukan pasar dan masyarakat sipil secara bertanggungjawab. Dan bagaimana mereka memainkan peran dalam mengelola sumberdaya ekonomi, politik dan kebudayaan yang tersedia dalam masyarakat.

Governance sebuah konsepsi alternatif yang lebih menekankan pada interaksi antara negara dan masyarakat sipil, dimana pemerintah(an) dipandang sebagai proses multi arah, yaitu proses memerintah yang melibatkan pemerintah dengan unsurunsur di luar pemerintah. John Pierre dan Guy Peters memahami governance sebagai sebuah konsep yang berada dalam konteks hubungan antara sistem politik dengan lingkungannya, dan mungkin melengkapi sebuah proyek yang membuat ilmu politik mempunyai relevansi dengan kebijakan publik. Sedang UNDP (1997) memberikan pengertian sebagai sebuah konsensus dalam penyelengaraan pemerintahan (governance) yang meliputi domain negara (state), sektor swasta (private sector) dan lembaga swadaya masyarakat (civil society organization).

Dalam relasi ketiga domain utama tersebut, negara sebagai organisasi kekuasaan yang didasarkan pada kewenangan tertinggi dalam suatu wilayah tertentu, serta memiliki sekelompok orang yang mengakui dan taat kepada kekuasaan 
yang ada, maka komponen pemerintahan harus dapat melakukan cheks and balances untuk mengontrol kekusaan. Sedang sektor privat, melalui pendekatan ekonomi berkaitan dengan penciptaan kondisi dimana barang dan jasa (goods and sevices) berjalan dengan baik dengan dukungan lingkungan yang mapan untuk melakukan sektor swasta. Sektor swasta dibedakan dengan masyarakat sipil, dimana sektor swasta mempunyai hubungan dan pengaruh yang sangat besar terhadap kebijakan sosial, politik dan ekonomi yang dapat menciptakan iklim kondusif bagi pasar dan perusahaan itu sendiri, sehingga pemerintah dan sektor swasta memiliki korelasi yang erat dalam bingkai kerja yang disebut "incentives rewards".

Governance tidak saja tergantung pada pemerintah yang mampu memerintah dan sektor swasta yang mampu menyediakan lapangan kerja dan penghasilan, namun juga tergantung pada masyarakat sipil yang memfasilitasi interaksi sosial dan politik, serta memobilisasi berbagai kelompok dalam masyarakat untuk terlibat dalam aktivitas sosial, ekonomi dan politik. Organisasi masyarakat sipil selain dapat memperkuat unsur utama dalam relasi ini, juga dapat menyalurkan partisipasi masyarakat dalam aktivitas sosial dan politik serta mengorganisasikannya ke dalam suatu kelompok yang lebih potensial untuk mempengaruhi kebijakan publik dalam mencapai kesejahteraan bersama.

Perspektif governance mempunyai sejumlah ortodoksi baru dalam mengelola negara bersandar pada enam prinsip utama, pertama, negara tetap menjadi pemain kunci bukan dalam pengertian dominasi dan hegemoni, namun negara sebagai aktor setara (primus inter pares) yang mempunyai kapasitas memadai untuk memobilisir aktoraktor masyarakat dan pasar untuk mencapai tujuan bersama. Kedua, negara bukan lagi sentrum "kekuasaan formal" tetapi sebagai sentrum "kapasitas politik". Kekuasaan negara harus ditransformasikan dari "kekuasaan atas" (power over) menuju "kekuasaan untuk" (power to). Ketiga, negara harus berbagi kekuasaan dan peran pada tiga level : ke atas pada organisasi transnasional, ke samping pada NGO dan swasta dan kebawah pada daerah dan masyarakat lokal. Keempat, negara harus melonggarkan kontrol politik dan kesatuan organisasinya agar mendorong segmensegmen di luar negara mampu mengembangkan pertukaran dan kemitraan secara kokoh, otonom dan dinamis. Kelima, negara harus melibatkan unsur-unsur masyarakat dan swasta dalam agenda pembuatan keputusan dan pemberian layanan publik. Keenam, penyelenggara negara harus mempunyai kemampuan responsif, adaptasi dan akuntabilitas publik.

Pada dasarnya penyelenggaraan pemerintah dalam good governance ditujukan kepada terciptanya fungsi pelayanan publik (public service) dengan baik, yang tidak hanya terbatas pengunaan peraturan perundang-undangan, dan tidak hanya melibatkan negara, tetapi harus melibatkan sistem birokrasi maupun ekstern birokrasi. Namun demikian model governance tidak selalu baik, namun dapat pula menjadi buruk. Demikian juga nilai baik (good) dimaknai berbeda. Bank Dunia memberi batasan good governance sebagai pelayanan publik yang efesien, sistem peradilan yang dapat diandalkan, serta pemerintah yang bertanggung jawab pada publiknya. Komunitas Eropa merumuskan sebagai pengelola kebijakan ekonomi yang masuk akal, pengambilan keputusan yang demokratis, transparasi pemerintahan dan tanggung jawab financial yang memadai, pencipta lingkungan yang bersahabat dengan pasar bagi pembangunan, langkah-langkah untuk memerangi korupsi, penghargaan terhadap aturan hukum, penghargaan terhadap HAM, kebebasan pers dan ekspresi.

Perbedaan standarisasi dan pemaknaan nilai Good pada model governance tersebut tidak pernah berada dalam titik konsepsinya, namun negara dalam melaksanakan manajemen kepemerintahannya akan cenderung kearah poros pasar, atau ke poros masyarakat sipil. Sebuah skema arus global, penduduk, uang, berita, image, data, militer, barang-barang, 
jasa dan ide dapat mengarah ke national market dan nasional society. Sebuah skema Global Policy Stakeholders, Tehranian mengambarkan skema global governance institutions sebagai berikut:

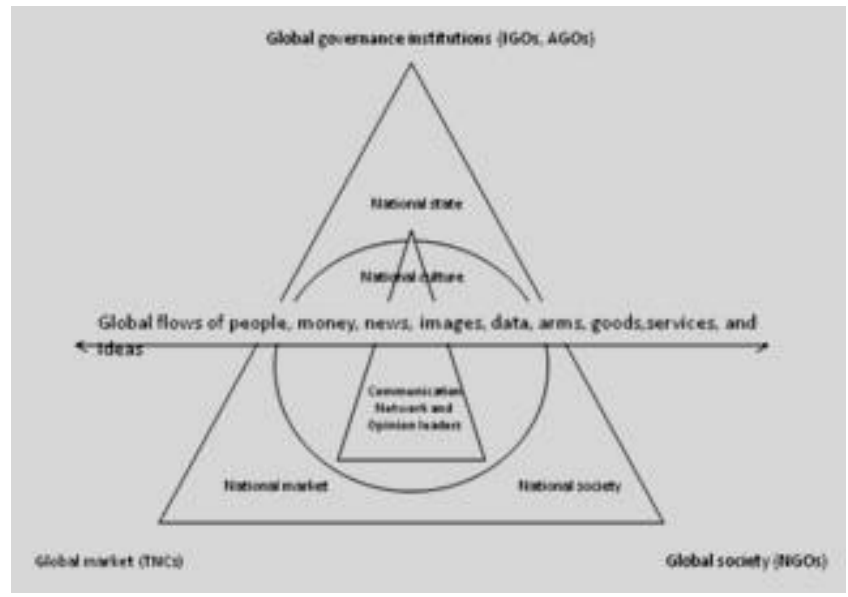

Gambar 1. Skema global governance institutions

Sumber : diambil dari M Tehranian (1999)

Nampak bahwa model governance suatu negara tidak dapat lepas dari model global governance, model Global akan menempatkan model nasional governance dalam konteks arus global yang melanda sistem nasional yang ada. Sehingga paradigma dan spektrum politik dalam implementasi good governance secara nasional akan diwarnai oleh spektrum politik global yang berkembang disekitarnya. Bila dilihat dari "Remaping the Global Political Spectrum" yang dikemukakan oleh Tehranian terdapat empat kutub spektrum state capitalism, libertarian capitalism dan totalitarian capitalism, dan communitarian capitalism. Dalam ruang pendulum spektrum politik global terdapat ruang antara state capitalism dengan communitarian capitalism berupa state welfare dengan NGO enveronmentalists. Sedang ruang antara liberal capitalism dengan communitarian capitalism terdapat ruang Corporate welfare dengan IGO environmentalists.

Dengan demikian konsepsi good governance sebagai model kebijakan akan sangat rentan dalam pendulum spectrum nasional maupun internasional. Bagaimana goodwill sebuah sistem akan menetapkan dalam pendulum poros yang ada dalam spectrum yang ada. Namun demikian goodwill pemerintah tidak cukup mencapai titik equilibrium dengan melihat dari spectrum nasional, namun akan dihadapkan arus tekanan global yang memungkinkan menyeret Negara dalam poros tertentu. Sehingga idialisme penggunaan konsep good Governance sebagai kebijakan dalam menyeimbangkan relasi yang seimbang hanya akan menjadi sebuah otopi, sebuah konsepsi retorik yang digunakan untuk menjustifikasi setiap kebijakan yang dilakukan pemerintah dalam suatu Negara.

\section{KESIMPULAN}

Dinamika akselerasi perubahan global sepanjang sejarah yang tidak pernah ada akhirnya, telah melahirkan terminologiterminologi peran negara, pasar dan masyarakat sipil serta kebijakan good governance sebagai model orientasi manaJemen pemerintahan. Orientasi kebijakan nasional melalui kekuatan politik akan selalu mengambil posisi dengan stressing yang berbeda pada masing-masing pemerintahan. Meskipun dalam menggembangkan tiga domains good

Jurnal Bricolage Vol. 2 No. 2 
governance diharapkan dapat bersinergi dan sejajar, arus globalisasi akan menyeret kebijakan nasional ke dalam poros domain tertentu. Hal ini dapat terjadi karena konsepsi ini meyakini bahwa konsep demokratisasi menjadi pilihan di banyak negara, dan demokratisasi pemerintahan diyakini bisa menjadi kunci untuk mencapai tertib sosial dan distribusi sumber daya yang adil. Dengan demokrasi kosmopolitan dapat terjadi tarik menarik peran secara tersentralisasi, terpolarisaikan atau terintegrasi dalam relasi tiga domains pemerintahan dan kekuatan politiklah yang akan memberi arah manajemen pemerintahan yang dianggap terbaik.

Mengintegrasikan ketiga domain secara simultan dan sejajar adalah sebuah kenisbian, ruang antara state dan civil society dengan national market dan civil society akan selalu menjadi ruang yang akan diambil dalam kebijakan nasional suatu bangsa, sebagai pengaruh dari spektrum politik global. Hongkong sebagai bekas koloni Inggris sebuah studi tentang iklan multi media di Bus sebagai ruang publik, memperlihatkan bahwa check and balances yang diperlukan untuk mengembangkan tanggung jawab sosial kapitalisme, tidak dapat berjalan, aliansi pemerintah dengan pengusaha memperlemah peran masyarakat sipil. Demikian pula beberapa kajian di negara-negara Amerika Latin dengan strategi melakukan reformasi birokrasi negara dengan merestrukturisasi institusiinstitusi di sektor sosial ekonomi good gvernance lebih diarahkan pada partisipasi civil society, namun dalam implementasinya kekuatan civil society tidak mampu menghadapi tekanan pasar. Dengan melakukan deregulasi perpajakan negara menekan penerimaan pajak yang dikembangkan dalam mekanisme pasar telah mereduksi menurunkan public service. Hal ini menunjukkan bahwa keseimbangan dan kesejajaran sinergi ketiga domain good governance tidak dapat ditemukan dalam tataran empirik.

\section{DAFTAR PUSTAKA}

Abrahansen, Rita, Disciplining Democracy, Development Discourse and Good Governance in Afrika, 2000, (www.media.wiley.com/product_data/excerpt/41/07879584/0787958 441.Pdf)

Catherine W Ng and Evelyn G H Ng, State, Market and Civil Society in Hong Kong : A study of Multi-Media Advertising on Buses, Asian Journal Of Public Administration, Vol 24, No 2 (december 2002) p.287-303

Chomsky, Noam. Neo imperialisme Amerika Serikat, Resist Book, Yogyakarta, 2008, hlm 183.

Dunleavy, Patrick. Brendan O'Leary, Theories of the State, The Politcs Of Liberal democracy, New Amsterdam Books, 171 Madison Avenue, New York. 1987.

Edward, Michael. Civil Society, http://www.infed.org/association/civ il society.htm. Direction of Ford Foundation

Edward, Michael, op.cit. http://www.infed.org/association/civ il society.htm. Direction of Ford Foundation p.2

Edward, Michael, op.cit. http://www.infed.org/association/civ il society.htm. Direction of Ford Foundation p.4

Ezazi,Shahla. Civil society and Democracy, paperback Vienna-Austria, Summer,2008-06-08. id.wikipedia.org/wiki/Civil society.

Faulks, Keith, Sosiologi Politik, pengantar kritis, terjemahan, Political Sociology:A Critical Introduction, Penerbit Nusa media, Ujung berung Bandung,2010.

Jurnal Bricolage Vol. 2 No. 2 
Faulks, Keith. Sosiologi Politik, pengantar kritis, terjemahan dari Political Sociology : A Critical Introduction, Penerbit Nusa Media, Bandung, 2010,

Gladstone,David. Hooshang Amirahdi, Towards a Dynamic Theory of the Sate and Civil Society in the Development Process, Journal of Planning Education and Research,16:15-25@1996. P.16. http://jpe.sagepub.com,

Good Governance: Definition and Implications, www.festanzania.org/doc/goodgovernance.Pdf.

Kuper, Adam.and Jessica Kuper, Ensiklopedi ilmu-ilmu sosial, Peneribit Pt. Raja Grafindo Persada Jakarta, 2000

Magnis suseno, Strategi kebudayaan,1992, hlm 100

Marnia, Nes. Good Governance, Good Local Governance, www.p2kp.org/pustaka/files/modul_ pelatihan $08 / \mathrm{D} / 2 / \mathrm{d} /$ modul-goodgavernance.pdf.

Martinussen, John, Society, State \& Market, Aguide to competing theories of development, Zed Books Ltd,7 Cynthia Street, London, 1997.

Nordlinger, Eric.A. On the autonomy of the democratic state, Harvard University Press, Cambridge, Massachusetts and London, England, 1981.
Paul Heinz Koestero, Tokoh-tokoh ekonomi mengubah dunia :Pemikiran yang mempengaruhi hidup kita, Penerbit Gramedia, Jakarta, $1987^{1}$

Rodee, Carlton Clymer. Carl Quimby Christol,Totton James Anderson, Thomas H Greene. Pengantar ilmu politik, Penerbit PT.Raja Grafindo Persada, Jakarta,2008.

Siebert, "Communication and Goverment' dalam Wilbur Schramm, ed, Mass Communications. Edisi kedua. Urbana,III: University of Illinois Press, 1960.

Rira abrahamsen, op.cit, www.media.wiley.com/product_data/excerpt/41/07879584/0787958 441.Pdf

Rivers L William, Jay W. Jensen, Theodore Peterson, Media Massa Dan Masyarakat Modern, Edisi kedua, Penerbit Prenada Media, Jakarta, 2003,

Vellinga, Meno,State, market and civil society : Latin American development in comparative perspective, Investgaciones Geograficas, Boletin del Instituto de Geografia,UNAM, ISSN 01884611,Num 